S.N. BAHUGUNA, Premila BAHUGUNA

Toxicology

\title{
IMPACT OF PHENTHOATE TOXICITY ON SOME FUNCTIONAL ASPECTS OF NITROGEN METABOLISM IN TISSUES OF THE FISH BARILIUS VAGRA (HAM.)
}

\section{WPEYW TOKSYCZNOSCI FENTONIANU NA PEWNE FUNRCJONALNE ASPERTY METABOLIZMU AZOTOWEGO U RYBY BARILIUS VA GRA (HAM.)}

\author{
Department of Zoology \\ University of Garhwal, Srinagar
}

\begin{abstract}
The protein value from the tissue decreased with a raise in the free ammonia acid level in the fishes exposed to sublethal concentrations of phenthoate. However ammonia and urea contents and the activity levels of glutamate dehydrogenase showed variable trend among the tissue during phenthoate intoxication. The findings are discussed in relation to the adaptability of the fish by recycling the toxic ammonia to the less toxic urea and towards the synthetic processes under phenthoate toxic impact.
\end{abstract}

\section{INTRODUCTION}

Pesticides and insecticides are playing an important role in agriculture production for man. On the other hand, when these indiscriminate release into the aquatic environment has resulted in the alteration and elimination of valuable components of the ecosystem, in which fishes mostly occupy (Legator et. al. 1969, Holden 1972). Livingston (1977) pointe $\perp$ out that due to high activity of pesticides and insecticides, they constitute an immediate danger to fish and other water organisms. The biological activity of the 
organophosphorous insecticides is generally attributed as the cause of the inhibition of the enzyme, acetylcholinesterase. However, their impact on other than $\mathrm{AChE}$ inhibition can not be ignored, since histo-pathological and haematological changes were reported during pesticide poisoning (Datta and Dikshith 1973). The enhanced glycolytic activity and increased protein tum over were also reported during organophosphate impact on Tilapia mossambica by Siva Prased (1980). However, literature on physiological changes associated with nitrogen metabolism, which is very important for the survival of the fish, is very scanty. The present paper deals with the sublethal impact of phenthoate on selected tissues in relation to tissue proteolysis, the fate of ammonia and its derivatives of the fresh water fish Barilius vagra (Hamilton). Phenthoate (0-0-dimethyl S(0-ethocarbonyl) phosphorothiolothionate) is widely used pesticide in this area, where Barilius vagra is a widely available and edible fish in the small tributaries of this region.

\section{MATERIAL AND METHODS}

The fish, Barilius vagra, were collected from the different tributaries of Ganga river around Srinagar (Garhwal) and acctimatised to laboratory conditions for a week by keeping them in glass troughs. The technical grade phenthoate, obtained from the horticulture department Srinagar Garhwal where supplied by Motilal Pesticides India Pvt. Ltd., New Delhi was used for the present study. The standard stock solution of phenthoate was prepared in acetone by taking $1 \mathrm{mg} / 1 \mathrm{ml}$ equivalent to $1000 \mathrm{ppm}$. $\mathbb{L C} 50$ value of phenthoate to $B$. vagra for 48 hours was determined by probit analysis (Finny 1964) and it is found to be $0.386 \mathrm{ppm}$. The quantity of acetone used in the present study is nontoxic to the fishes. Hence, $0.125 \mathrm{ppm}$ concentration of phenthoate was selected, since it represents sublethal concentration (Konar 1969), and the fishes were exposed for $48 \mathrm{~h}$. The troughs containing phenthoate exposed (PE) fishes were aerated frequently to prevent the hyepoxic condition of the medium. Controls were recived similar treatment except the addition of phenthoate.

From exposed fishes, muscle, gill and liver were isolated and kept in cold. For glutamate dehydrogenase (GDH-EC 1.4.1.3) the tissues were homogenised in $0.25 \mathrm{M}$ cold sucrose solution and centrifuged at $1000 \mathrm{~g}$ for 15 minutes. The supernatant was used for the enzyme assay. For proteins and ammonia, the tissues were homogenised in distilled water, in 10\% TCA for free amino acids and in 15\% PCA for urea.

The GDH was estimated by the method of Lee and Lardy (1965) after due standardisation. The proteins were estimated by the method of Lowry et al. (1951); free aminoacids, by the method of Moore and Stein (1957); ammonia; by the method of Bergmeyer (1965); and uria, by the method of Natelson (1971). The mean values of control and $\mathbb{P E}$-fishes were subjected to statistical analysis using student $t$-test (Bailey 1965). 


\section{RESULTS AND DISCUSSION}

The data, presented in table 1 , show the following trends. The total protein of the tissue decreased with a rise in the free amino acid level in all the tissues of phenthoate-exposed fishes. However the decrease in gill proteins is insignificants increased in liver tissues and decreased in muscle and gill tissues. The activity levels of glutamate dehyrogenase (GDH) showed alterations under phenthoate intoxication.

The total proteins decreased with a corresponding increase in free amino acids in all the tissues under phenthoate impact, suggestive of increased proteolytic activity to meet the excess demands of energy during stress condition. Increased proteolytic activity during malathion impact in T. mossambica was reported earliar (Kabeer 1979). The high level of free amino acids might be fed into the TCA cycle as keto acids during transamination reactions, transaminoses were found to increase during organophosphate poisoning (Siva Prasad 1980).

The activity of glutamate dehydrogenase showed a significant decrease in muscle tissue and an insignificant increase in gill and liver tissue. The significant decrease of GDH activity in muscle tissue suggests diminised oxidative deamination process under phenthoate impact. This is in consonance with our observation that there is low levels of ammonia under pesticide exposure (Table-1). The decreased levels of ammonia in gill suggests the excretion of ammonia from this tissue by way of diffusion, or it might be utilised in a different way. In liver tissue, there is a significant increase in the ammonia level with an insignificant increase in GDH activity, inferring effective opration of deamination process and the increased level of ammonia might be utilised for amino acid and protein synthesis via Glutamine formation under impending circumstances, increased Glutamine content supports the Finding of Siva Prasad et al. (1981) and increase of protein value (Siva Prasad 1980).

Urea content decreased in muscle and gill tissues, whereas an increase was observed in liver tissue during toxic stress. The result obtained for muscle and gill tissue were insignificant. The presence of Urea is notable, since teleosts are known to synthesize Urea (Wakell etal. 1973). The increased level of ammonia with enhanced levels of Urea contants suggests the stepped up conversion of toxic ammonia to less toxic Urea. Thus it can be inferred that phenthoate interacts with the biochemical sequences of nitrogen metabolism and the animal tries to adapt to the toxic stress condition by converting the toxic ammonia to less toxic Urea and also enhancing the synthetic potentiality of the tissues.

\section{ACKNOWLEDGEMENTS}

M" sincere thanks are due to Prof. H.R. Singh, Head Department of Zoology for providing necessary facility and CSIR New Delhi for the financial support. 
Table 1

Levels of total proteins, free amino acids (mg/g wet wt.); ammonia, Urea (UM/g wet wt.) and activity levels of glutamate dehydrogenase (GDH) ( $\mu \mathrm{M}$ of formazon formed/mg protein $/ \mathrm{h}$ ) in muscle, gill and liver tissues of control and Phenthoate-exposed (PE) fishes.

(Each value is a mean \pm S.D. of individual observations. $P=t$-test NS - not significant. The signs + or - indicates the percent increase or decrease over control).

\begin{tabular}{|c|c|c|c|c|c|c|}
\hline \multirow[b]{2}{*}{ Content/Enzyme } & \multicolumn{2}{|c|}{ Muscle } & \multicolumn{2}{|c|}{ Gill } & \multicolumn{2}{|c|}{ Liver } \\
\hline & Control & $\begin{array}{l}\text { Exposed with } \\
\quad \mathrm{PE}\end{array}$ & Control & $\begin{array}{c}\text { Exposed with } \\
\text { PE }\end{array}$ & Control & $\begin{array}{c}\text { Exposed with } \\
\text { PE }\end{array}$ \\
\hline Total proteins & $\begin{array}{r}280.50 \\
\pm 8.45\end{array}$ & $\begin{array}{l}240.45 \\
\pm 10.25 \\
-14.27 \% \\
\text { P } 0.001\end{array}$ & $\begin{array}{r}196.28 \\
\pm 9.86\end{array}$ & $\begin{array}{l}179.26 \\
\pm 8.76 \\
-8.67 \% \\
\text { NS }\end{array}$ & $\begin{array}{r}158.43 \\
\pm 6.24\end{array}$ & $\begin{array}{r}130.46 \\
\pm 5.97 \\
-11.34 \% \\
\text { P } 0.025\end{array}$ \\
\hline Free amino acids & $\begin{array}{l}10.85 \\
\pm 1.05\end{array}$ & $\begin{array}{r}15.82 \\
\pm 0.47 \\
+45.80 \% \\
\text { P } 0.001\end{array}$ & $\begin{array}{l}10.47 \\
\pm 0.98\end{array}$ & $\begin{array}{c}16.21 \\
\pm 1.39 \\
+54.82 \% \\
\text { P } 0.001\end{array}$ & $\begin{array}{l}18.61 \\
\pm 0.89\end{array}$ & $\begin{array}{c}29.37 \\
\pm 0.92 \\
457.82 \% \\
\text { P } 0.001\end{array}$ \\
\hline Ammonia & $\begin{array}{r}7.65 \\
\pm 0.80\end{array}$ & $\begin{array}{c}5.37 \\
\pm 0.21 \\
-29.80 \% \\
\text { P } 0.001\end{array}$ & $\begin{array}{r}3.04 \\
\pm 0.32\end{array}$ & $\begin{array}{c}2.06 \\
\pm 0.32 \\
-32.23 \% \\
\text { P } 0.001\end{array}$ & $\begin{array}{l}12.21 \\
\pm 1.97\end{array}$ & $\begin{array}{c}17.29 \\
\pm 0.91 \\
-41.60 \% \\
\text { P } 0.001\end{array}$ \\
\hline Urea & $\begin{array}{l}11.86 \\
\pm 1.25\end{array}$ & $\begin{array}{c}10.27 \\
\pm 0.78 \\
-13.41 \% \\
\text { NS }\end{array}$ & $\begin{array}{l}11.57 \\
\pm 1.02\end{array}$ & $\begin{array}{l}10.53 \\
\pm 0.96 \\
-9.35 \% \\
\text { NS }\end{array}$ & $\begin{array}{r}9.39 \\
\pm 0.66\end{array}$ & $\begin{array}{r}12.80 \\
\pm 0.88 \\
-36.32 \% \\
\text { P } 0.001\end{array}$ \\
\hline GDH & $\begin{array}{r}0.4005 \\
\pm 0.0131\end{array}$ & $\begin{array}{c}0.3104 \\
\pm 0.0086 \\
-22.50 \% \\
\text { P } 0.001\end{array}$ & $\begin{array}{r}0.1929 \\
\pm 0.0089\end{array}$ & $\begin{array}{l}0.2240 \\
\pm 0.0405 \\
+16.12 \% \\
\quad \text { NS }\end{array}$ & $\begin{array}{r}0.5206 \\
\pm 0.0212\end{array}$ & $\begin{array}{r}0.5865 \\
\pm 0.0264 \\
+12.65 \% \\
\text { NS }\end{array}$ \\
\hline
\end{tabular}




\section{REFERENCES}

Bailey, N.T.J., 1965: Statistical methods in Biology. The english language book Society and English Uniwersity Press Ltd. Great/B ritain.

Bergmeyer, H.U., 1965: Methods of enzymatic analysis. Academic Press New York.

Datta, K.K., Dikshith, T.S.S., 1973: Histo-pathological changes in the testis and liver of rats repeatedly exposed to pesticides. Exp. Path. 8:363-370.

Finny, D.J., 1964: Probit analysis 2nd Ed Camb. Uni. Press London.

Holden, A.V., 1972: The effect of pesticides on life in freshwater. Proc. $\mathbb{R}$. Soc. Lond. B $180: 383-384$.

Kabeer, A.Il., 1979: Studies on some aspects of protein metabolism and associated enzyme systems in the fresh water teleost. T. mossambica (Peters), Ph.D. Thesis S.V.Uni. Tripati India.

Konar, S.K., 1969: In Environmental pollution by pesticides Ed. CA.Edwards (London \& New York: Plenum Press)

Lee, Y.L., Lardy, H.A., 1965: Influence of thyroid hormonce on L.glycerophosphate dehydrogenase and other dehydrogenases in various organs of the rat. J.Biol.Chem. 193:240:1427.

Legator, M.S., Palmer, K.A., Green, S., Peterson, K.W., 1969: Cytogenic studies in rats of cyclohexylamine, a metabolite of cyclamate. Science, 165:1139.

Livingston, $\mathbb{R} . J_{.}, 1977$ : Review of current literature concerning the acute and chronic effects of pesticides on aquatic organisms, Critic Environ. Control., 7, 4:325-351.

Lowry, O.H., Rosenbrough, J.J., Farr, A.L., Randall, R.J., 1951: Protein measurement with the folin-phenol reagent. J.Biol.Chem., 193: 265-275.

Moore, S., Stein, W.H., 1957: In methods in enzymology Ed. colowick, S.P. and Kaplan, N.O. (New York, Acad. Press), 3:468.

Natelson, S., 1957: Techniques in clinical chemistry. Charles C.Thomas Pub., Springfied, Illinois, USA,P-146.

Siva, $\mathbb{P}_{0} \mathbb{R}_{0} \mathbb{K}_{0}, 1980$ : Studes on some aspects of Metabolic changes with emphasis on carbohydrate utilisation in cell-free system of the Teleost-Ph.D. Thesis S.V.Uni. Tirupati.

Siva, P.R.K., Kabeer, A.K.I., Rao, R.K.V., 1981: Impact of methyl parathion on the tissue $\mathrm{NH}_{3}$-changes in the fish, T. mossambica (Peters). Proc. Indian Natn. Sci. Acad. B 47, 394-397.

Wakell, M., Marleen, Bo, Brown, G.W., 1973: Orinithine aminotransferase of fishes.Comp. Bioch. Physiol. 46: 779-795.

\section{S.N. Bahuguna i Premila Bahuguna}

\section{WPEYW TOKSYCZNOŚCI FENTONIANU NA PEWNE FUNKCJONALNE ASPEKTY METABOLIZMU AZOTOWEGO U RYBY BARILIUS VA GRA (HAMILTON)}

\section{STRESZCZENIE}

U ryb poddanych działaniu subletalnych stężeń fentonianu, wzrostowi wolnych aminokwasów towarzyszył spadek wartości białka. W trakcie intoksykacji fentonianowej notowano wahania w zawartości amoniaku i mocznika oraz w poziomie dehydrogenazy glutaminowej w mięśniach. 
Uzyskane wyniki przedyskutowano pod kątem możliwości adaptacyjnych ryb, polegających na przekształcaniu toksycznego amoniaku w mniej toksyczny mocznik oraz na procesach syntezy wywołanych toksycznym działaniem fentonianu.

Author's addreess:

Received: 2 January 1987

Dr. S.N. Bahuguna, P. Bahuguna

Department of Zoology

Garhwal University

Srinagar Garhwal -246 174 UP

INDIA 